\title{
VIP ACTIVATION OF RAT ANTERIOR PITUITARY ADENYLATE CYCLASE
}

\author{
P. ROBBERECHT, M. DESCHODT-LANCKMAN, J.C. CAMUS, P. DE NEEF, \\ M. LAMBERT and J. CHRISTOPHE* \\ Department of Biochemistry and Nutrition, School of Medicine, Université libre de Bruxelles, Boulevard de Waterloo 115 , \\ B-1000 Brussels, Belgium \\ Received 30 March 1979 \\ Revised version received 22 May 1979
}

\section{Introduction}

The brain gut octacosapeptide VIP (vasoactive intestinal peptide) is found in discrete areas in the cerebral cortex, the hypothalamus and the posterior pituitary gland $[1-4]$. Specific VIP binding sites are coupled to an adenylate cyclase system in synaptic membranes from guinea pig brain $[5,6]$.

Besides, the concentration of VIP in the hypothalamo-hypophysial portal vessels is much higher than in the systemic blood [7]. The peptide has however no established function in the hypophysis $[7,8]$. These data document the presence in the rat pituitary of functional VIP receptors existing in the form of a VIP-stimulated adenylate cyclase system and suggest that VIP might be a major peptidic activator of rat adenopituitary membrane adenylate cyclase.

\section{Materials and methods}

\subsection{Rat anterior pituitary homogenization and preparation of a crude particulate fraction}

Batches of 9 male Wistar albino rats (200-250 g) with free access to a standard diet and water were sacrificed at 09:00-10:00 by decapitation. The anterior pituitary lobes were rapidly separated from

\footnotetext{
Abbreviations: Gpp $(\mathrm{NH}) \mathrm{p}$, guanosine $5^{\prime}-(\beta, \gamma$-imido)triphosphate; VIP, vasoactive intestinal peptide; EGTA, ethylene glycol-bis(2-aminoethylether) $N, N, N^{\prime}, N^{\prime}$-tetraacetic acid; $P \mathrm{PE}_{2}$, prostaglandin $\mathrm{E}_{2}$

* To whom correspondence should be addressed
}

the neuropituitary gland whenever indicated and all subsequent steps were performed at $2-4^{\circ} \mathrm{C}$. Each pool was homogenized separately in $5 \mathrm{ml} 20 \mathrm{mM}$ Tris- $\mathrm{HCl}$ buffer ( $\mathrm{pH} 7.4$ ) containing $0.25 \mathrm{M}$ sucrose, $5 \mathrm{mM}$ 2-mercaptoethanol, $1 \mathrm{mM}$ EDTA and $2 \mathrm{mM}$ $\mathrm{MgCl}_{2}$, by 7 up-and-down manual strokes with a glass-Teflon homogenizer. The anterior pituitary homogenate was submitted to a $180 \times \mathrm{g}, 10 \mathrm{~min}$ centrifugation. The supernatant was centrifuged at $4000 \times \mathrm{g}$ for $15 \mathrm{~min}$ and the resulting pellet was resuspended in the homogenizing buffer and immediately assayed for its adenylate cyclase activity and later on for its protein content [9].

\subsection{Adenylate cyclase assay}

The incubation medium contained $0.5 \mathrm{mM}$ $\left[\alpha{ }^{32}\right.$ P]ATP, $2 \mathrm{mM}$ cyclic AMP, $6 \mathrm{mM} \mathrm{MgCl} 2,0.5 \mathrm{mM}$ EGTA, $1 \mathrm{mM}$ 2-mercaptoethanol, $1 \mathrm{mM}$ theophylline, $10 \mathrm{mM}$ phospho(enol)pyruvate, $30 \mu \mathrm{g} / \mathrm{ml}$ pyruvate kinase and $30 \mathrm{mM}$ Tris- $\mathrm{HCl}$. The $\mathrm{pH}$ was adjusted to 7.4 at $25^{\circ} \mathrm{C}$. The reaction was initiated by the addition of $10 \mu \mathrm{l}$ crude homogenate or rehomogenized pellet (10-50 $\mu \mathrm{g}$ protein). The total volume of the incubation was $60 \mu \mathrm{l}$. Under all conditions tested, the enzymatic kinetics were linear for at least $10 \mathrm{~min}$ at $37^{\circ} \mathrm{C}$. In routine assays, the reaction was stopped after $10 \mathrm{~min}$ at $37^{\circ} \mathrm{C}$ by adding $0.5 \mathrm{ml} 0.5 \%$ sodium dodecylsulfate solution containing $1.5 \mathrm{mM} \mathrm{ATP}$, $0.5 \mathrm{mM}$ cyclic AMP and cyclic $\left[8 \cdot{ }^{3} \mathrm{H}\right] \mathrm{AMP}$ (20 $000 \mathrm{cpm}$ for determination of cyclic nucleotide recovery). The separation of cyclic AMP was achieved by the double column procedure [10]. 


\subsection{Peptides and reagents}

Synthetic secretin, $\left[\mathrm{Val}^{5}\right]$ secretin, $\left[\mathrm{Ala}^{4}\right]$ secretin, $\left[\mathrm{D} \cdot \mathrm{Ala}^{4}\right]$ secretin, $\left[\mathrm{Glu}^{3}\right]$ secretin, $\left[\mathrm{Asn}^{3}\right]$ secretin, and secretin(7-27) were generous gifts of Dr W. König (Hoechst Aktiengesellschaft, Frankfurt); essentially pure natural porcine VIP was prepared by Dr V. Mutt (Karolinska Institutet, Stockholm) and supplied by the National Institutes of Health (Bethesda, MD); bombesin was synthesized by Dr R. de Castiglione (Farmitalia Montedison, Milano); the C-terminal octapeptide of pancreozymin and somatostatin were gifts from, respectively, Dr S. J. Luciana (Squibb Institute for Medical Research, Princeton, NJ) and

Dr R. Deghenghi (Ayerst Research Laboratories, Montreal, Quebec). Porcine glucagon was supplied by Novo Industries (Copenhagen) and TRH, LH-RH, Met-enkephalin, and Leu-enkephalin were purchased from Union Chimique Belge (Brussels). $\mathrm{PGE}_{1}$ and $\mathrm{PGE}_{2}$ were generous gifts from Drs D. A. van Dorp and D. N. Nugteren (Unilever, Vlaardingen). ATP, GTP, Gpp(NH)p, phospho(enol)pyruvate and pyruvate kinase were obtained from Sigma Chemical Co.

(St Louis, MO). Cyclic $\left[8 \cdot{ }^{3} \mathrm{H}\right] \mathrm{AMP}$ and $\left[\alpha{ }^{32} \mathrm{P}\right] \mathrm{ATP}$ from the Radiochemical Centre (Amersham) had a specific radioactivity of, respectively, $27 \mathrm{Ci} / \mathrm{mmol}$ and $1-10 \mathrm{Ci} / \mathrm{mmol}$. All others reagents were of the highest grade available.
3. Results and discussion

\subsection{Specificity of a VIP-sensitive adenylate cyclase activity in pituitary homogenates}

Orientation experiments conducted on total rat pituitary homogenates allowed the detection of an adenylate cyclase activity stimulated by VIP, the guanyl nucleotides GTP and $\mathrm{Gpp}(\mathrm{NH}) \mathrm{p}$, and by sodium fluoride. At an optimal $10^{-6} \mathrm{M}$ concentration, VIP stimulated the enzyme 1.8-2.0-fold (not shown). This VIP activation was mostly confined to the anterior portion of the gland (table 1, panel A) since a 3-fold stimulation of basal adenylate cyclase activity was observed in adenohypophysis homogenates as compared to a 1.4-fold stimulation only in posterior pituitary homogenates. Stimulations evoked by VIP and by GTP or Gpp(NH)p were purely additional (table 1, panel B).

The activation of adenylate cyclase by VIP in anterior pituitary homogenates was already significant at a low $3 \times 10^{-9} \mathrm{M}$ VIP concentration (fig.1). The dose-effect curve appeared biphasic with one component maximally stimulated at VIP concentrations in the $3 \times 10^{-8} \mathrm{M}$ range, and a second component maximally stimulated at high $3 \times 10^{-7}-1 \times 10^{-6} \mathrm{M}$ concentrations. A similar biphasic curve of VIP. stimulated adenylate cyclase activity was also observed

Table 1

Adenylate cyclase activity in homogenates of male rat adenohypophysis and posterior hypophysis

\begin{tabular}{|c|c|c|c|}
\hline Expt & Addition & Adenohypophysis & Posterior hypophysis \\
\hline \multirow[t]{5}{*}{ A } & None & $48=6$ & $52 \pm 7$ \\
\hline & $10^{-5} \mathrm{M}$ GTP & $61 \pm 6$ & $67 \pm 7$ \\
\hline & $10^{-5} \mathrm{M} \mathrm{Gpp}(\mathrm{NH}) \mathrm{P}$ & $140 \div 15$ & $124 \pm 10$ \\
\hline & $10^{-6} \mathrm{M}$ VIP & $151 \pm 15$ & $75 \pm 7$ \\
\hline & $10 \mathrm{mM} \mathrm{NaF}$ & $382 \pm 20$ & $398 \pm 20$ \\
\hline \multirow[t]{6}{*}{ B } & None & $43 \pm 2$ & \\
\hline & $10^{-s} \mathrm{M}$ GTP & $65=5$ & \\
\hline & $10^{-5} \mathrm{M} \mathrm{Gpp}(\mathrm{NH}) \mathrm{p}$ & $108 \pm 13$ & \\
\hline & $10^{-6} \mathrm{M}$ VIP & $134 \pm 15$ & \\
\hline & $10^{-5} \mathrm{M} \mathrm{GTP}+10^{-6} \mathrm{M} \mathrm{VIP}$ & $166 \mp 20$ & \\
\hline & $10^{-5} \mathrm{M} \mathrm{Gpp}(\mathrm{NH}) \mathrm{p}+10^{-6} \mathrm{M}$ VIP & $191 \pm 23$ & \\
\hline
\end{tabular}

The data are expressed as pmol cyclic AMP formed min $^{-1}$.mg protein ${ }^{-1}$. Means \pm SEM of 4 (A) and 6 (B) expt performed in duplicate under standard conditions as detailed in section 2 


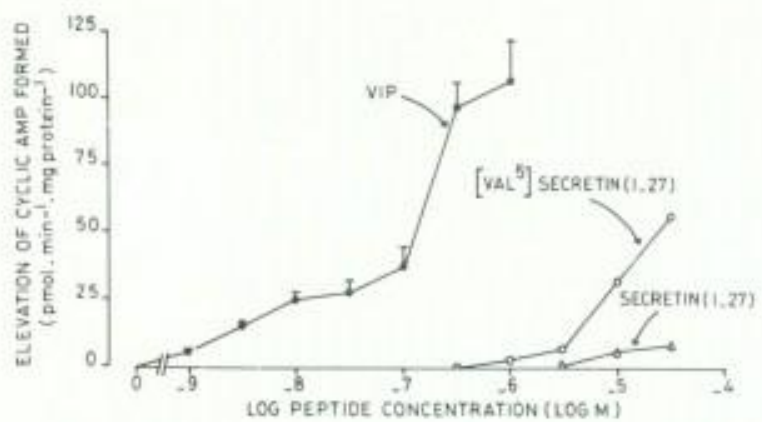

Fig.1. Dose-response curves of adenylate cyclase activity stimulated by natural VIP (•- $\bullet$ ), synthetic secretin $(\Delta-\Delta)$ and synthetic $\left[\mathrm{Val}^{5}\right]$ secretin $(0-0)$ in adenopituitary homogenates from male rats. The dose-effect curve for VIP is the mean \pm SEM of 6 expt performed in duplicate. The secretin and $\left[\mathrm{Val}^{5}\right]$ secretin dose-effect curves are the means of 3 expt. Results are expressed in pmol cyclic AMP formed min $^{-1}$.mg protein ${ }^{-1}$ in excess of the basal unstimulated value. The mean basal activities were $41 \pm 2$ and $43 \mathrm{pmol} \mathrm{min}^{-1}, \mathrm{mg}$ protein ${ }^{-1}$ for, respectively, the first and the two last dose-effect curves.

in membrane preparations (fig. 3 and vide infra). This might suggest the existence of two functionally distinct classes of VIP receptors having, respectively, high affinity-low capacity and low affinity-high capacity. Conceivably, these distinct classes of VIP receptors might originate from the same or from different cell types.

Among the parent peptides tested (including secretin, glucagon, $\left[\mathrm{Val}^{5}\right]$ secretin, $\left[\mathrm{Glu}^{3}\right]$ secretin, $\left[\mathrm{Asn}^{3}{ }^{3}\right.$ secretin, $\left[\mathrm{Ala}^{4}\right]$ secretin, [D-Ala $\left.{ }^{4}\right]$ secretin and the secretin fragment $(7-27)$, only two were found to be weak activators of the adenopituitary adenylate cyclase. Secretin was efficient only at a very high $3 \times 10^{-5} \mathrm{M}$ concentration. $\left[\mathrm{Val}^{5}\right]$ secretin with the $\mathrm{Thr}^{5}$ residue in secretin replaced by $\mathrm{Val}^{5}$ (the amino acid residue present in the same position in VIP) proved to be more efficient than secretin at $3 \times 10^{-6} \mathrm{M}$ but yet 100 -fold less potent than VIP. This peptide has the same relatively high potency on the adenylate cyclase activity of guinea pig brain membranes (P.R. et al., unpublished data).

A series of neuropeptides normally present in the hypothalamus, including TRH, LH-RH, Met-and Leu-enkephalin, somatostatin, bombesin and the C-terminal octapeptide of pancreozymin were unable to affect adenylate cyclase activity when offered at
$1 \times 10^{-8}-3 \times 10^{-5} \mathrm{M}$ and in the absence as well as in the presence of VIP (data not shown). This was perhaps surprising considering that hypothalamic factors such as TRH, LH-RH and the ill-defined GH$\mathrm{RH}$ factor are supposed to act on anterior pituitary cells by increasing intracellular cyclic AMP levels. The published evidence in favor of this uncertain role of cyclic AMP includes:

1. Increases in cyclic AMP levels in pituitary glands incubated in the presence of the peptide factors and of a phosphodiesterase inhibitor:

2. Stimulation of secretion and synthesis of pituitary hormones by dibutyryl cyclic AMP [11,12].

This view has been challenged, however, since a direct activation of pituitary adenylate cyclase by TRH and LH-RH could not be demonstrated in crude extracts as well as in pure plasma membranes, even when a guanyl nucleotide was added $[13,14]$.

At variance with these negative results, we observed a stimulation of adenylate cyclase activity with $\mathrm{PGE}_{1}$ (not shown) and with $\mathrm{PGE}_{2}$ (fig.2). This stimulation and that of VIP proved to be additive (fig.2). Prostaglandins $E_{1}$ and $E_{2}$ are known to stimulate the release of rat anterior pituitary hormones including ACTH [15], growth hormone [16] and prolactin [12-16] and to activate rat anterior pituitary adenylate cyclase [17]. The purely additive effects of VIP and prostaglandins on adenylate cyclase activation suggest the independence of both stimulations. It remains to be established whether both agents acted upon plasma membranes from distinct cell types or on independent catalytic subunits from the same cell membranes.

\subsection{Characteristics of adenylate cyclase activity of $180 \times \mathrm{g}$ to $4000 \times \mathrm{g}$ pellets}

Further experiments were conducted on $180 \times g$ to $4000 \times \mathrm{g}$ sediments. The effects of VIP, secretin analogs, neuropeptides and prostaglandins were basically identical to those exerted on total homogenates, with only one major difference (fig.3). GTP and $\mathrm{Gpp}(\mathrm{NH}) \mathrm{p}$, at concentrations giving maximal intrinsic activity, increased 2 -fold the amount of cyclic AMP produced in the presence of VIP alone. This clear potentiation of VIP by both guanyl nucleotides makes the VIP-sensitive adenylate cyclase system of adenopituitary particulate fraction comparable to that of mouse liver [18] and rat pancreas [19]. This might result from the elimination of labile 


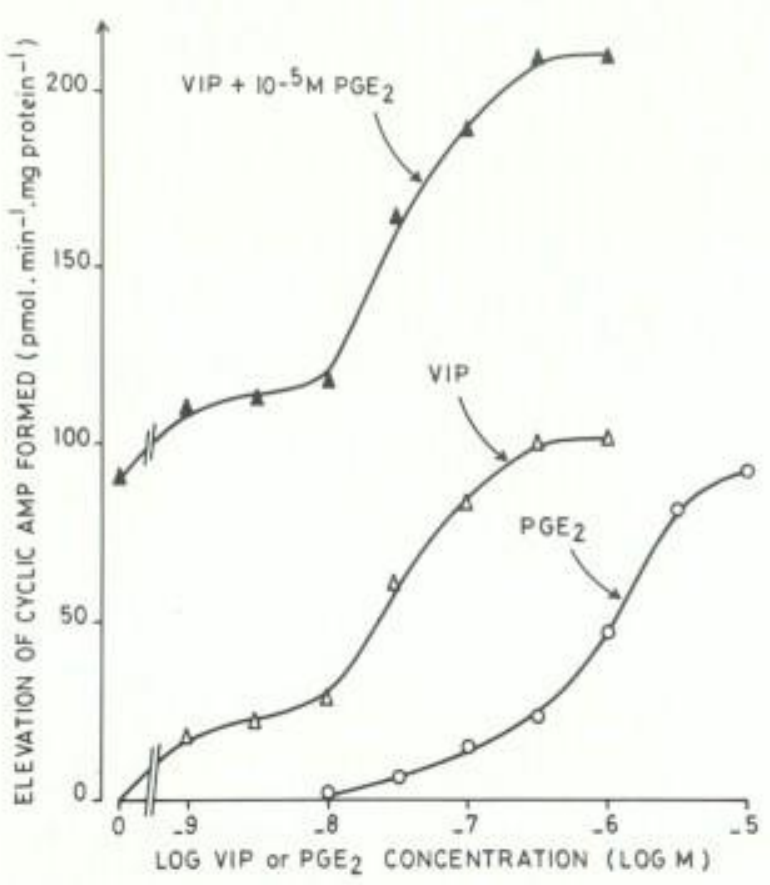

Fig.2. Dose-response curves of adenylate cyclase activity stimulated by $\mathrm{PGE}_{2}(\mathrm{O}-0)$, VIP $(\Delta-\Delta)$ or by VIP in the presence of $10^{-1} \mathrm{M} \mathrm{PGE}_{2}(\mathbf{}-\Delta)$ in adenopituitary homogenates from male rats. The results are the mean of 3 expt and are expressed in pmol cyclic AMP formed $\mathrm{min}^{-1}$ mg protein ${ }^{-1}$ in excess of the basal unstimulated value. The mean basal activity was 50 pmol cyclic AMP . $\min ^{-1}$,mg protein $^{-1}$.

endogenous guanyl nucleotides and/or protein factors acting like GTP [20] that were responsible for the relatively high basal activity of adenylate cyclase as well as for the lack of potentiation of VIP by exogenous GTP or Gpp(NH)p in a crude homogenate (see table 1).

As in adenopituitary homogenate, the stimulatory effects of prostaglandins $E_{1}$ and $E_{2}$ and those of VIP were additive in the adenopituitary particulate fraction. In the latter case, the presence of GTP was required for adenylate cyclase activation by the prostaglandins (data not shown).

The biological significance of the present data might be of importance. Up to now, VIP was reported [8] to cause a dose-related increase in plasma prolactin when injected into the third ventricle or intravenously to rats. This effect was suppressed by naloxone and by L-dopa and could not be reproduced in vitro on

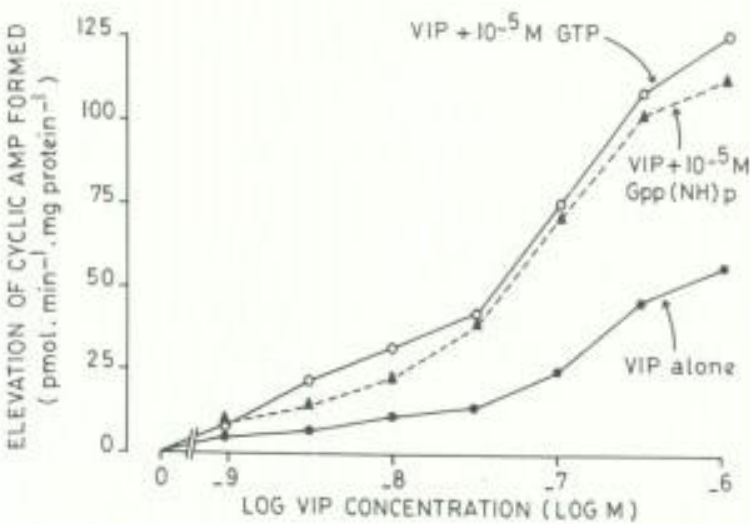

Fig. 3. Dose-response curves of adenylate cyclase activity stimulated by natural VIP, in the absence (-—) or in the presence of $10^{-5} \mathrm{M} \mathrm{GTP}(\mathrm{o}-0)$ or $10^{-5} \mathrm{M} \mathrm{Gpp}(\mathrm{NH}) \mathrm{p}$ $(\mathbf{A}-\mathbf{4})$ in an adenopituitary particulate fraction. This fraction was the resuspended $4000 \times g$ pellet obtained after centrifugation of the $180 \times \mathrm{g}$ supernatant of an adenopituitary homogenate from male rats. The dose-effect curves were the means of 4 expt performed in duplicate. The results were expressed in pmol cyclic AMP formed $\mathrm{min}^{-1} \mathrm{mg}$ protein ${ }^{-1}$ in excess of the corresponding control values, i.e.,

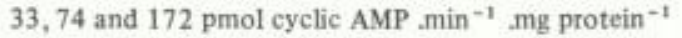
formed, respectively, in the absence of any addition, and in the presence of $10^{-s} \mathrm{M} \mathrm{GTP}$ or $10^{-5} \mathrm{M} \mathrm{Gpp(NH)p.} \mathrm{The}$ values found in the presence of nucleotides were significantly higher than those observed in the absence of nucleotides ( $p<0.001$ based on Student's $t$ test for paired values).

cultured pituitary cells. Similar in vivo and in vitro effects on the release of growth hormone were observed [7]. These data suggest that VIP might act on hormone secreting cells of the adenohypophysis through opiate receptors. The present demonstration of VIP receptors coupled to an adenylate cyclase indicates as an added mechanism the direct involvement of VIP in adenopituitary adenylate cyclase system(s). This biological event might be related to the stimulation of prolactin release by VIP recently demonstrated in incubated anterior pituitaries from male rats [21].

\section{Acknowledgements}

Aided by grant 20,403 from the Fonds de la Recherche Scientifique Médicale, Belgium and grant R0-1 AM-17010 from the National Institutes of Health, USA. 


\section{References}

[1] Larsson, L. I., Fahrenkrug, J., Schaffalitzky de Muckadell, O., Sundler, F., Hâkanson, R. and Rehfeld, J. F. (1976) Proc. Natl. Acad. Sci. USA 73, 3197-3200.

[2] Fuxe, K., Hokfelt, T., Said, S. I. and Mutt, V. (1977) Neurosci. Lett. 5, 241-246.

[3] Said, S. I. and Giachetti, A. (1977) in: Hormonal Receptors in Digestive Tract Physiology (Bonfils, S., Fromageot, P. and Rosselin, G. eds) pp. 417-423, Elsevier/North-Holland, Amsterdam, New York.

[4] Van Noorden, S., Polak, J. M., Bloom, S. R. and Bryant, M. G. (1978) Scand. J. Gastroenterol. 13. suppl. $49,189$.

[5] Robberecht, P., De Neef, P., Lammens, M., DeschodtLanckman, M. and Christophe, J. P. (1978) Eur. J. Biochem. 90, 147-154.

[6] Deschodt-Lanckman, M., Robberecht, P. and Christophe, J. (1977) FEBS Lett. 83, 76-80.

[7] Said, S. I., Porter, J. C., Vijayan, E., Samson, R. and Mc Cann, S. M. (1978) Scand. J. Gastroenterol. 13. suppl. $49,154$.

[8] Kato, Y., Iwasaki, Y., Iwasaki, J., Abe, H., Yanaihara, N. and Imura, H. (1978) Endocrinology 103,554-558.

[9] Lowry, O. H., Rosebrough, N. J., Farr, A. L. and Randall, R. J. (1951) J. Biol. Chem. 193, 265-275.

[10] Salomon, Y., Londos, C, and Rodbell, M. (1974) Anal. Biochem. 58, 541-548.
[11] Borgeat, P., Chavancy, G., Dupont, A., Labrie, F., Arimura, A. and Schally, A. V. (1972) Proc. Natl. Acad. Sci. USA $69,2677-2681$.

[12] Labrie, F., Pelletier, Lemay, A., Borgeat, P., Barden, N., Dupont, A., Savary, M., Coté, J. and Boucher, R. (1973) Acta Endocrinol., suppl. 180, 301-340.

[13] Theoleyre, M., Berault, A., Garnier, J.and Jutisz, M. (1976) Mol. Cell. Endocrinol. 5, 365-377.

[14] Clayton, R. N., Shakespear, R. A. and Marshall, J. C. (1978) Mol. Cell. Endocrinol. 11, 63-78.

[15] Peng, T. C., Six, K. M. and Munson, P. L. (1969) Fed. Proc. FASEB 28, 437.

[16] MacLeod, R. M. and Lehmeyer, J. E. (1970) Proc, Natl. Acad, Sci. USA 67, 1172-1179.

[17] Deery, D. J. and Howell, S. L. (1973) Biochim. Biophys. Acta 329, 17-22.

[18] Robberecht, P., Deschodt-Lanckman, M., Dehaye, J. P. and Christophe, J. (1978) in: Gut Hormones (Bloom, S. R. ed) pp. 97-103, Churchill Livingstone, Edinburgh, London, New York.

[19] Svoboda, M., Robberecht, P., Camus, J., DeschodtLanckman, M. and Christophe, J. (1978) Eur. J. Biochem. 83, 287-297.

[20] Pecker, F, and Hanoune, J. (1977) J. Biol, Chem. 252, 2784-2786.

[21] Ruberg, M., Rotsztejn, W. H., Arancibia, S., Besson, J. and Enjalbert, A. (1978) Eur. J. Pharmacol. 51, $319-320$. 